\title{
Aura-MLS Observations of Water Vapor Entering the Stratosphere over the Northern Bay of Bengal and East Equatorial Indian Ocean
}

\author{
Kizhathur Narasimhan Uma ${ }^{1, *}$, Subrata Kumar Das ${ }^{2}$, Siddarth Shankar Das ${ }^{1}$, \\ and Karanam Kishore Kumar ${ }^{1}$ \\ ${ }^{1}$ Space Physics Laboratory, Vikram Sarabhai Space Centre, Trivandrum, India \\ ${ }^{2}$ Physical Meteorology and Aerology Division, Indian Institute of Tropical Meteorology, Pune, India
}

Received 10 July 2012, accepted 6 November 2012

\begin{abstract}
The space-time variations in water vapor in the upper troposphere and lower stratosphere (UTLS) over the Asian summer monsoon (ASM) regions are investigated using six years of observations from the Aura-MLS to understand the ASM role in transporting water vapor to the tropical stratosphere. While some previous studies indicated that the ASM plays a role in dehydrating the lower stratosphere, the present investigations revealed that the ASM region plays an active role in hydrating rather than dehydrating the tropical lower stratosphere. The analysis also shows that only during the month of August (ASM) is moist air pumped into the lower stratosphere over the two key geographical locations (India and Western Pacific). The air parcel from the tropical tropopause takes approximately 10 - 12 months to reach the mid-stratosphere with an ascent rate of $2.8 \times 10^{-4} \mathrm{~m} \mathrm{~s}^{-1}$. Thus it is envisaged that the present results will have important implications in understanding the exchange processes across the tropopause and its role in stratosphere chemistry.
\end{abstract}

Key words: Stratospheric water vapour, MLS, Asian summer monsoon

Citation: Uma, K. N., S. K. Das, S. S. Das, and K. K. Kumar, 2013: Aura-MLS observations of water vapor entering the stratosphere over the northern Bay of Bengal and East Equatorial Indian Ocean. Terr. Atmos. Ocean. Sci., 24, 357-368, doi: 10.3319/TAO.2012.11.06.01(A)

\section{INTRODUCTION}

It has been known over the last few decades that water vapor is a key greenhouse gas in the upper troposphere and lower stratosphere (UTLS) region and plays a crucial role in the radiative, chemical and dynamical properties of the atmosphere. It is a major source of the hydroxyl $(\mathrm{OH})$ radical, the primary oxidant in the atmosphere, which is important for ozone chemistry. Its distribution is strongly influenced by both large-scale circulation and localized convection. There has been renewed scientific attention towards water vapor transport and the factors that control its transport from the troposphere into the stratosphere and vice-versa (e.g., Danielson 1982; Sherwood and Dessler 2000, 2001; Wang et al. 2011 and references therein; Randel et al. 2012).

Water vapor mixing ratio observations in the lower stratosphere have played a critical role in understanding how, when and where air enters from the troposphere into

\footnotetext{
* Corresponding author

E-mail:urmi_nmrf@yahoo.co.in
}

the stratosphere. Many observations in the past reported a dry tropical stratosphere in contrast to the wet tropical stratosphere given the large quantities of water vapor in the tropical troposphere and its transport to the lower stratosphere. Brewer (1949) provided the first hypothesis for tropical stratosphere dryness, which is limited to the tropics where the tropopause is cold enough to freeze dry the air. However, Newell and Gould-Stewart (1981) (hereafter NG81) pointed out that occurring in preferential seasons and regions over the Bay of Bengal (BoB) during the Boreal-summer and western Pacific during the Boreal-winter. Holton et al. (1995) proposed that the transport of moist air from the troposphere to the stratosphere generally occurs in a two-step process, viz. (i) rapid convective motion and (ii) slow diabatic ascent. Extensive studies were carried out on the transport processes, viz. direct injection of overshooting convection (e.g., Danielson 1982; Sherwood and Dessler $2000,2001)$ and the advection of slow ascending air crossing the cold tropical tropopause, (Holton and Gettelman 2001; Fueglistaler et al. 2005). Recent studies have brought 
attention to water vapor in the UTLS region (Mote et al. 1996; Gettelman et al. 2002; Gulstad et al. 2007). Considerable effort has been made to understand in detail, how the air entering the stratosphere gets dehydrated. However, the issue is still debated. This issue is very important as the stratospheric water vapor also plays a major role in ozone depletion and the radiative balance of the stratosphere. Another factor which needs to be understood in this context is the time scale required for such transport.

The water vapor in the UTLS region is difficult to detect due to its large variability and smaller magnitude. It is also difficult to accurately determine its concentration at that height region. The global water vapor coverage is possible only through space borne measurements [e.g., AuraMicrowave Limb Sounder (MLS)], though the temporal resolution is poor but provides a better opportunity for simultaneous global water vapor measurements in the UTLS region. At this juncture, these observations can be very useful in exploring the stratosphere-troposphere exchange (STE) processes and also in identifying the mechanisms responsible for stratospheric dehydration. In this regard, we have tried to provide observational evidence and the time scales involved in the exchange processes, with an emphasis on the role of the Asian summer monsoon (ASM) in hydrating/dehydrating the tropical lower stratosphere. The main intent of this communication is to examine the water vapor profiles in the UTLS region over two selected regions and to discuss the exchange processes taking place between the troposphere and stratosphere in light of the present understanding of such processes. It is envisaged that the present analysis will shed light on the complicated process involved in the transport mechanism across the tropopause and subsequent dehydration/hydration of the stratosphere.

\section{AURA-MLS}

The microwave limb sounder on board the Aura satellite provides simultaneous global measurements of various chemical species including water vapour in the lower and middle atmosphere. The Aura-MLS observes thermal microwave - far infrared emissions from the Earth's atmosphere in 5-spectral regions. The water vapor measurement described in this study is from Version 3.3 - Level 2 retrieved from $183 \mathrm{GHz} \mathrm{H}_{2} \mathrm{O}$ rotational line spectrum measurements (Livesey et al. 2011). MLS observations are available at different pressure levels and the data are useful from 316 to $0.002 \mathrm{hPa}$. The vertical resolution for $\mathrm{H}_{2} \mathrm{O}$ is in the $2.0-$ $3.7 \mathrm{~km}$ range from $316-0.22 \mathrm{hPa}$ and degrades to $6-11 \mathrm{~km}$ for pressures lower than $0.22 \mathrm{hPa}$. The along track horizontal resolution is $210-360 \mathrm{~km}$ for pressures greater than $4.6 \mathrm{hPa}$, and degrades to $400-740 \mathrm{~km}$ at lower pressures. The horizontal cross-track resolution is the $7 \mathrm{~km}$ full width half maximum of the MLS 190-GHz field-of-view for all pressures. and $200-300 \mathrm{~km}$ along track (Lambert et al.
2007; Read et al. 2007). The data span of the present study is from August 2004 to December 2011. More details about the instrument, algorithms and science products can be found in Waters et al. (2006) and also in the website http:// mls.jpl.nasa.gov. For water vapor, typical single profile precisions are $0.9,0.7,0.5$, and $0.3 \mathrm{ppmv}$ at $215,147,100 \mathrm{hPa}$, lower stratosphere, respectively (Livesey et al. 2011). The typical estimated precision of the temperature measurement is $\sim 1 \mathrm{~K}$ at $100 \mathrm{hPa}$ (Froidevaux et al. 2006). We have also utilized interpolated daily mean Outgoing Long wave Radiation (OLR) from NCEP/NCAR reanalysis (Kalnay et al. 1996), which are available at a grid resolution of $2.5^{\circ}$ latitude $\times 2.5^{\circ}$ longitude.

\section{OBSERVATIONAL RESULTS}

Figure 1a shows the latitude-longitude OLR contour map over the ASM for the months of January (left panel) and August (right panel) averaged from 2004 - 2011. The OLR is considered to be the proxy for the intensity of conviction. The inner and outer closed contours indicate the OLR < 200 and 220 watts $\mathrm{m}^{-2}$, respectively. During January, low OLR $<220$ watts $\mathrm{m}^{-2}$ is observed over East Equatorial Indian Ocean (EEIO), as shown in Fig. 1a (right panel). But in the month of August, an ASM season, low value of OLR $<220$ watts $\mathrm{m}^{-2}$ is observed over the entire Bay of Bengal and as well as over the EEIO. However, strong convective zone (OLR $<200$ watts $\mathrm{m}^{-2}$ ) is observed over the North Bay of Bengal (NBoB). Newell and Gould-Stewart (1981) and Gettelman et al. (2002) also pointed out that over the tropics, deep convection occurs over these two regions (NBoB and EEIO) in addition to the western Pacific. Thus, for the present study, we considered these two regions with a spatial coverage of 5 degree $\times 5$ degree: (i) $\mathrm{NBoB}$ between 15 $-20^{\circ} \mathrm{N}$ and $87.5-92.5^{\circ} \mathrm{E}$, and (ii) EEIO between $5-0^{\circ} \mathrm{S}$ and $92.5-97.5^{\circ} \mathrm{E}$ as indicated by the rectangle in Fig. 1a.

In order to verify the seasonal convection characteristics, a time-series of the monthly mean OLR is plotted for the NBoB and EEIO from $2004-2011$, as shown in Fig. 1b. The vertical bars indicate the standard error. From Fig. 1b (left panel) it is evident that low OLR values $\left(<220 \mathrm{~W} \mathrm{~m}^{-2}\right)$ were observed over the $\mathrm{NBoB}$ region during only JuneSeptember, whereas over the EEIO region, low OLR values $\left(<220 \mathrm{~W} \mathrm{~m}^{-2}\right)$ were observed throughout the year because the ascending branch of the Hadley cell is situated in the EEIO vicinity. The OLR magnitudes $<180 \mathrm{~W} \mathrm{~m}^{-2}$ are also observed, which clearly shows the persistence of deep convective clouds to a very large vertical extent over the above regions. During the low OLR seasons deep convective clouds with a large vertical extent will be formed, which will cause a huge amount of rainfall. Hence, whenever there is a deep convection, it is envisaged that a substantial amount of water vapor must be pumped up to and above the tropopause. 

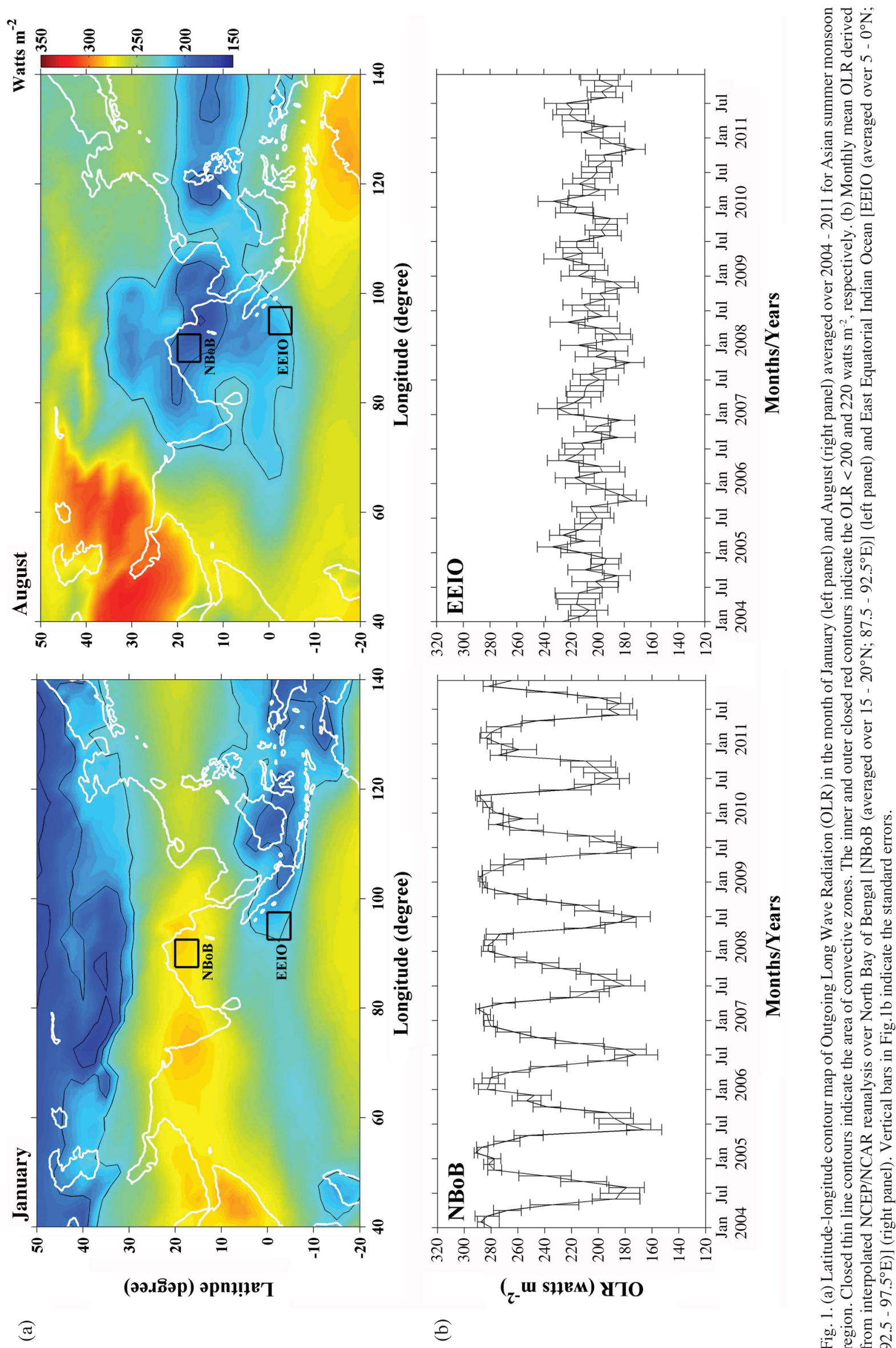

(วว.ภิวр) วрп!!ฺย T

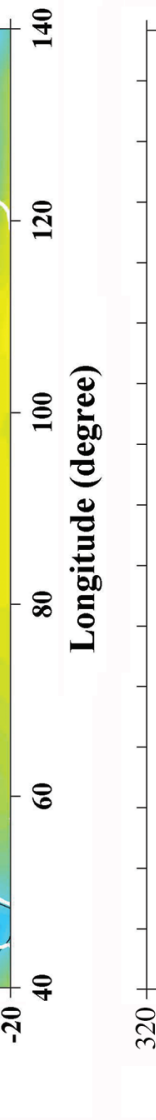

$\hat{e}$

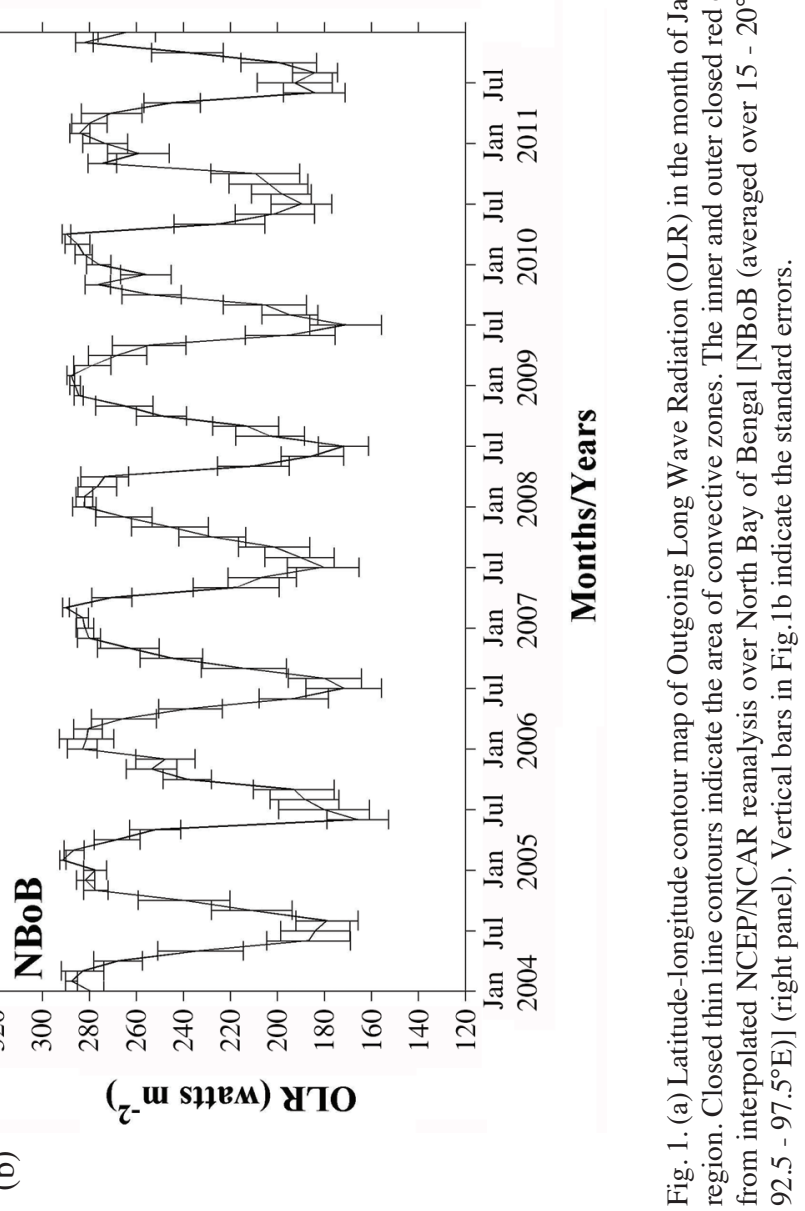


Figure 2a shows the monthly mean height distribution of water vapor mixing ratio derived from the Aura-MLS for the NBoB (left panel) and EEIO (right panel). The water vapor mixing ratio is plotted separately for the lower-tropopause layer (260 - $140 \mathrm{hPa})$ and UTLS $(120$ - $30 \mathrm{hPa})$. The standard water vapor error showed in Fig. $2 b$ shows that the present results are significant. From these figures observed during the month of June - September, the water vapor concentration is greater in the mid troposphere as well as in the UTLS region for NBoB. This is because during these months, the Indian sub-continent and surrounding oceanic regions, experience the ASM. On the other hand, over the EEIO the water vapor concentration is high throughout the year in the lower troposphere. This is expected as the ascending branch of the Hadley cell is situated in the EEIO vicinity as discussed above and indicated by the low OLR value. One of the common interesting features observed at both $\mathrm{NBoB}$ and EEIO, is that the water vapour concentration in the lower stratosphere i.e., above the tropopause $(>100 \mathrm{hPa}$ ) remains the same irrespective of the availability of water vapour in the troposphere. Both regions show the water vapor penetration in the month of August to September, which will be discussed in the upcoming section.

To provide further insight, we also plotted the monthly mean spatial water vapor mixing ratio distribution (Lat-Lon) at different pressure levels (viz., 215, 100 and $68 \mathrm{hPa}$ ) for January, August, and October averaged from 2005 - 2011, shown in Fig. 3. The inner and outer closed contours indicate the OLR $<200$ and 220 watts $\mathrm{m}^{-2}$, respectively. It is observed that during the month of January, over the EEIO, where low OLR is observed throughout the seasons, the water vapour at $215 \mathrm{hPa}$ is found to be $>200 \mathrm{ppmv}$, but on the other hand, the water vapour at $100 \mathrm{hPa}$, is found to be very low $(<3$ ppmv). In the month of August, the water vapor (a)
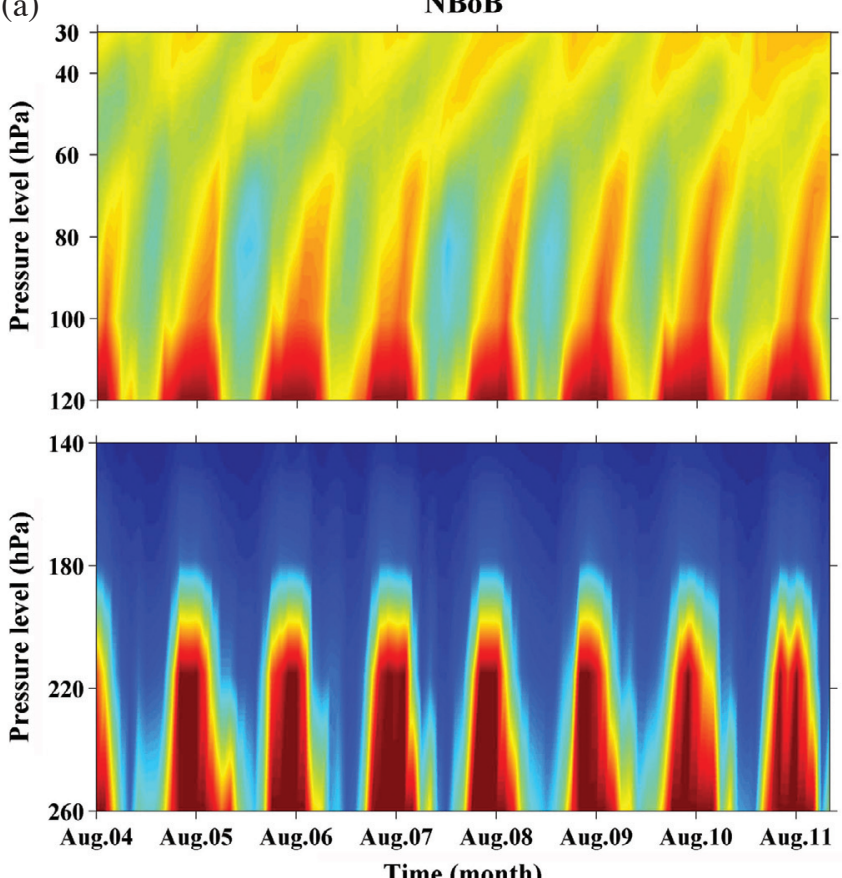

(b)

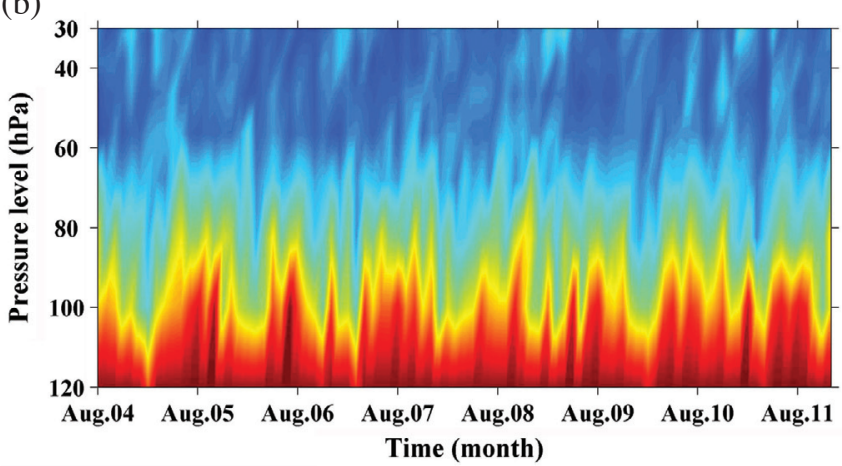

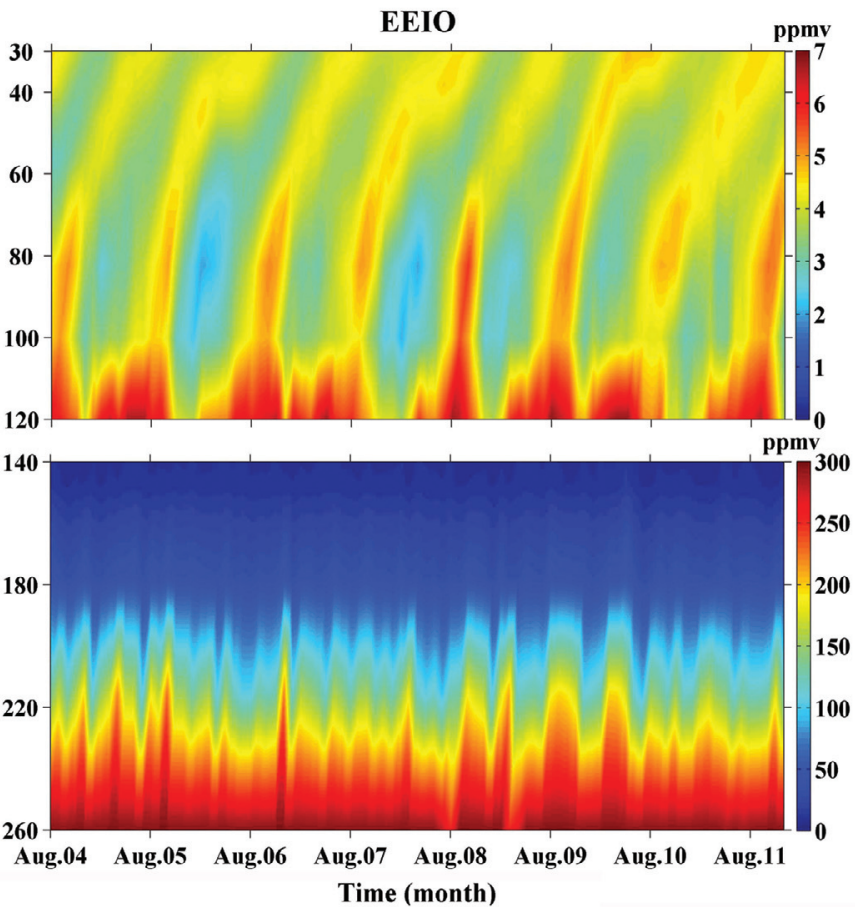

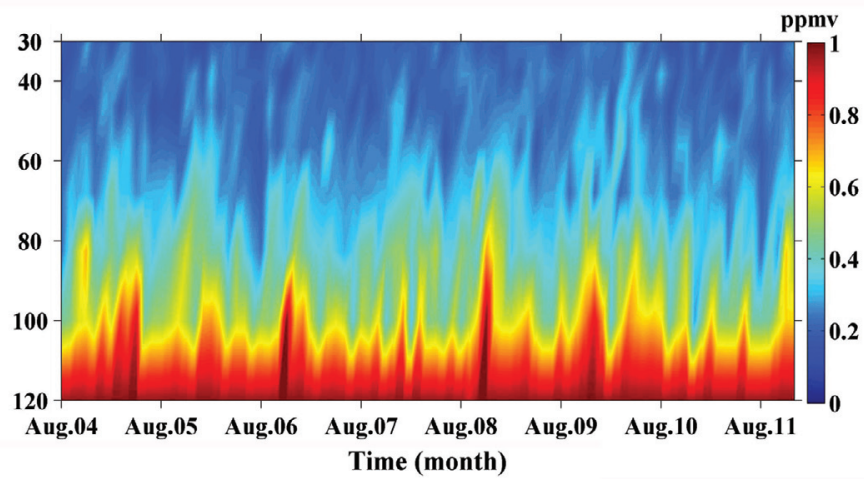

Fig. 2. (a) Monthly mean water vapor mixing ratio height distribution derived from Aura-MLS for NBoB and EEIO from 2004 - 2011. (b) Monthly mean height distribution of standard errors in the UTLS region. 


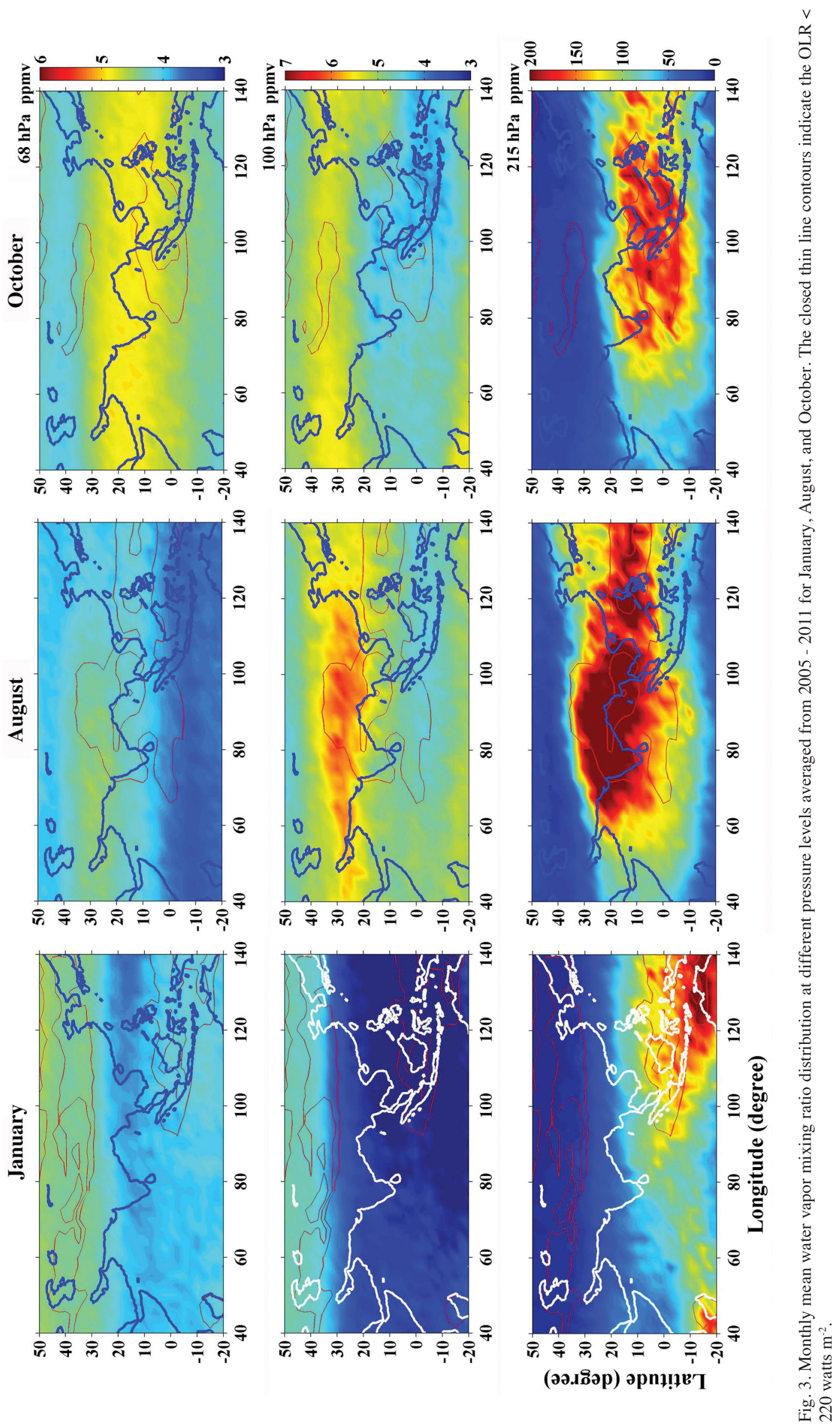


concentration shifted over the $\mathrm{NBoB}$ and northern part of the Indian region, found to be $>250 \mathrm{ppmv}$. At $100 \mathrm{hPa}$, relatively higher water vapor concentration $(6-7 \mathrm{ppmv})$ over the NBoB and northern part of the Indian region. Interestingly, a homogeneous water vapor distribution (2 - 3 ppmv) is found over the entire ASM region at $68 \mathrm{hPa}$. In the month of October the water vapor mixing ratio is confined to the EEIO at $215 \mathrm{hPa}$. It is noteworthy that the water vapor concentrations at $100 \mathrm{hPa}$ over the EEIO are much less $(<3 \mathrm{ppmv})$ although the water vapor availability is very high in the lower troposphere. Over the northern part of the Indian region there is relatively more water vapor (5 $6 \mathrm{ppmv}$ ) than in the EEIO region at 100 and $68 \mathrm{hPa}$. The ASM actively participates in hydrating the stratosphere compared to the EEIO, where the water vapor concentration is found to exist throughout the year. This indicates that the water vapor penetration and distribution in the middle stratosphere depends on the availability of water vapour in the troposphere and also on some other factors that need to be accounted for.

\section{DISCUSSION}

Atmospheric tracers in a transport model and trajectory models show that the transport from the boundary layer into the tropical tropopause layer (TTL) occurs in the regions prone to active convection (Levine et al. 2007). This is evident from Figs. 2 and 3 that the water vapor concentration is $6-7 \mathrm{ppmv}$ in the vicinity of the tropopause (VOT) during the ASM. Relatively dry tropopause can be observed during the winter over both of these regions. Thus, the onset of the ASM in June and its subsequent progress over the Indian subcontinent during July - September is responsible for the relatively large amount of water vapor in the VOT. During the ASM period $\sim 6-7$ ppmv of water vapor is observed in the VOT and around $5-6 \mathrm{ppmv}$ is observed in the lower stratosphere. The water vapor transport through observations (e.g., Newell and Gould-Stewart 1981; Park et al. 2007), modeling (e.g., Bannister et al. 2004; Lelieveld et al. 2007) and the Lagrangian analyses (e.g., Fueglistaler et al. 2005; Wright et al. 2011) are well-documented. Gettelman et al. (2002) observed through simulations that convection over the southern hemisphere moistens the TTL significantly throughout the depth and in deep convection the water vapor concentration may also increase in the stratosphere. Randel et al. (2012) showed the variability in water vapor and deuterated water vapor using the Fourier Transform Spectrometer on board the Atmospheric chemistry Experiment (ACE) mission. The profiles during the month of February, April, August and October were utilized to understand the structure and variability of water vapor. They also observed the well-known Tape-Recorder behavior as observed by Mote et al. (1996) but not in deuterated water vapor. They also observed the differential isotopic effects of convection in different locations. Wang et al. (2011) showed that midlatitude convective storms also inject water vapor and ice particles into the stratosphere using models. They attributed this to the storm top gravity wave breaking and turbulent mixing induced instability. Wang et al. (2009) showed that over Denver, jumping cirrus and overshooting top plumes inject water vapor into the stratosphere during the STEPS 2000 Colorado thunderstorm experiment. Schoeberl et al. (2012) observed that the dehydration mechanism takes place in both the South American and East Asian regions using three different models. Their model also reproduced the tape recorder signal of stratospheric water vapor. All of the above studies provided evidence that deep convection transports water vapor from the troposphere into the stratosphere. In this analysis we focused mainly on two important key geographical locations, viz., $\mathrm{NBoB}$ and EEIO, where the deep convection is strongest (NG81). This study also accounts for the differences in the stratospheric water vapor observed over these two key geographical locations. This study also provides insight into the other factors that control water vapor transport into the stratosphere. These factors will be explained further.

In the lower stratosphere $(<100 \mathrm{hPa})$ there is a relatively low water vapor concentration (4 - 8 ppmv) compared to the magnitudes observed at and below the VOT. The present observations of water vapor concentration in the lower stratosphere are in accordance with earlier studies carried out by Smith et al. (2000) and Randel et al. (2001) using HALOE water vapour measurements. Most of the earlier studies attributed this decrease in water vapor due to the dehydration of air while crossing the cold point tropopause (NG81; Sherwood and Dessler 2000; Jain et al. 2006; Jain et al. 2010). From Fig. 2 it is evident that the water vapor concentration just above the tropopause was maximum in the month of August consistently during all study years (2004 - 2011). This observation suggests that moist air crossed the tropopause during the month of August and was slowly lifted up by the large-scale ascent in the stratosphere. The tilt in the observed water vapor maxima in the stratosphere confirms this large-scale lifting of air from the tropopause. One should also note that the parcel moving through the tropopause retains its identity throughout the journey without getting dithered until it reaches up to $\sim 30 \mathrm{hPa}$. During the winter when the tropopause is coldest over the Indian sub-continent (Randel et al. 2000; Das et al. 2010), the air crossing the tropopause will be dehydrated and thus minimum water vapor is observed during this season, as shown in Fig. 2. At the same time the available water vapor during winter at the VOT is also low compared to the ASM season. During the ASM, even though the water vapor is available in the VOT during June-September over the $\mathrm{NBoB}$, the moist air enters the lower stratosphere only during the month of August. Over the EEIO where the deep convection prevails throughout the year, one should expect 
the pumping of moist air throughout the year. However, the entry of moist air takes place only in the month of August. This phenomenon needs to be investigated further.

In order to explore this aspect we analyzed the temperature derived from the Aura-MLS in the UTLS region for both the NBoB and EEIO, as shown in Fig. 4a. The minimum temperature in each profile is found at $100 \mathrm{hPa}$ and this is considered the cold point tropopause (Selkirk 1993). In the present analysis we consider the temperature at $100 \mathrm{hPa}\left(\mathrm{T}_{100}\right)$. Figure $4 \mathrm{~b}$ shows the monthly mean OLR, water vapour mixing ratio at $82 \mathrm{hPa}$ and temperature at $100 \mathrm{hPa}$ over the NBoB and EEIO. The vertical bars indicate the standard errors. The time series of monthly mean water vapour mixing ratio at $82 \mathrm{hPa}$ is found to increase or decrease with respect to $T_{100}$. As discussed above, the OLR $<200$ watts $\mathrm{m}^{-2}$ is observed during the month of August and enhanced water vapour at $82 \mathrm{hPa}$ is also observed over the NBoB. Whereas over the EEIO, throughout the year the OLR $<220$ watts $\mathrm{m}^{-2}$ but the enhanced water vapour at $82 \mathrm{hPa}$ is only observed during the month of August, as discussed above. It is clearly evident that during the month of August the $T_{100}$ shown in Fig. $4 b$ is warmer $\left(T_{100}>191 \mathrm{~K}\right)$ for both geographical regions. Note from Fig. $4 \mathrm{~b}$ that there is a time lag of $2-3$ months between the maximum water vapour and the maximum temperature. Figure 5 shows a scattered plot of the water vapor mixing ratio at $82 \mathrm{hPa}$ and temperature at $100 \mathrm{hPa}$ over the $\mathrm{NBoB}$ (Fig. 5a) and EEIO (Fig. 5b). This correlation was done for the data from August 2004 to December 2011. The correlation coefficient $(\mathrm{R})$ is found to be 71.5 and $70 \%$ for the NBoB and EEIO, respectively. This aspect suggests that the overshooting convective air parcel with relatively large water vapor (6 8 ppmv) can cross the tropopause only during the month of August, when the $T_{100}$ is warmer. Newell and Gould-Stewart (1981) explained that air enters the stratosphere only where the tropopause temperature is coldest. Earlier observations also showed that a cold tropopause temperature is observed over Bay of Bengal and the Indian tropical region during the pre-monsoon (March - May) and monsoon (June - August) months suggesting that the Indian tropical region may be participating in the stratospheric dehydration (Newell and Gould-Stewart 1981; Bannister et al. 2004; Jain et al. 2006, 2010). Highwood and Hoskins (1998) also observed that during June - August the ASM region plays a role in the stratospheric dehydration. Sherwood and Dessler (2001) showed that the dry air would have entered the stratosphere by overshooting convection, and thereafter gets freeze dried as it encounters the cold temperatures at the tropopause.

This study shows a different perspective, that if the tropopause temperature is warmer, then significant moist air enters the stratosphere thereby hydrating it. This occurs during the month of August, which is predominantly a monsoon season, hence showing that the ASM region also hydrates the stratosphere. However, episodic overshooting of convection and subsequent dehydration of the lower stratosphere is not ruled out during the ASM. On the monthly time-scales these episodic intrusions seem to be insignificant, as revealed by Fig. 2. From Fig. 2 (right panel) it is observed that even though the water vapor is available at around $120 \mathrm{hPa}$ throughout the year, it is not getting reflected in the lower stratosphere as mentioned earlier. Thus the above conditions, i.e., first the availability of moist air around TTL and second the warmer tropopause are simultaneously required for hydrating the lower stratosphere. During the winter season the air crossing the tropopause is dehydrated due to the extreme cold tropopause with temperatures around $<191 \mathrm{~K}$. However, during winter, if water vapor is available at the tropopause, it still cannot enter the lower stratosphere as it is restricted by the cold tropopause by dehydrating it. On the other hand, during the month of August as the $\mathrm{T}_{100}$ is around $194-197 \mathrm{~K}$, thereby allowing moist air into the stratosphere without dehydrating as discussed above. However, the moistening of the stratosphere depends on availability of water vapor in the VOT. This implies that even though the tropopause is warmer there should be water vapor in the VOT. This is where the role of the ASM is emphasized, which is responsible for transferring the moist air up to the VOT. Once the air parcel reaches the tropopause it is then taken aloft by large-scale vertical motions prevailing in the stratosphere (Potter and Holton 1995). Figure 2 shows that the air parcel takes $10-12$ months to reach the mid stratosphere over all of these regions. The estimated average ascent rate from the slope of the pressure - month section is around $2.8 \times 10^{-4} \mathrm{~m} \mathrm{~s}^{-1}$ and on the convection rapidly transports the air parcel from the lower troposphere to 200 hPa. Newell et al. (1969) and Kley et al. (1979) estimated that the zonally averaged time-mean upwelling velocities in the tropics through in-situ observations and found it to be $2 \times 10^{-4} \mathrm{~m} \mathrm{~s}^{-1}$. The present estimation is comparable with earlier results. Gettelman et al. (2002) showed that the convection has to reach the level of zero radiative forcing for air transport from the troposphere to the stratosphere. This clearly shows that the exchange between the troposphere and stratosphere is a two-step process (i) overshooting convection and (ii) slow ascent into the stratosphere. Sherwood and Dessler (2000) and Rao et al. (2008) also showed that the air transport from the boundary layer to the stratosphere is a two-step process with different time scales. However, these two step processes depend strongly on the tropopause temperature as saturated water vapor is strongly coupled with temperature. The moist air enters the stratosphere only during August, when the warm tropopause is observed over the tropics. This is clearly revealed for the first time in this study.

To provide further insight we showed the latitudeheight water vapor mixing ratio distribution in the UTLS region averaging between $67.5-97.5^{\circ} \mathrm{E}$ during the month of January, August and October in Fig. 6. These months 

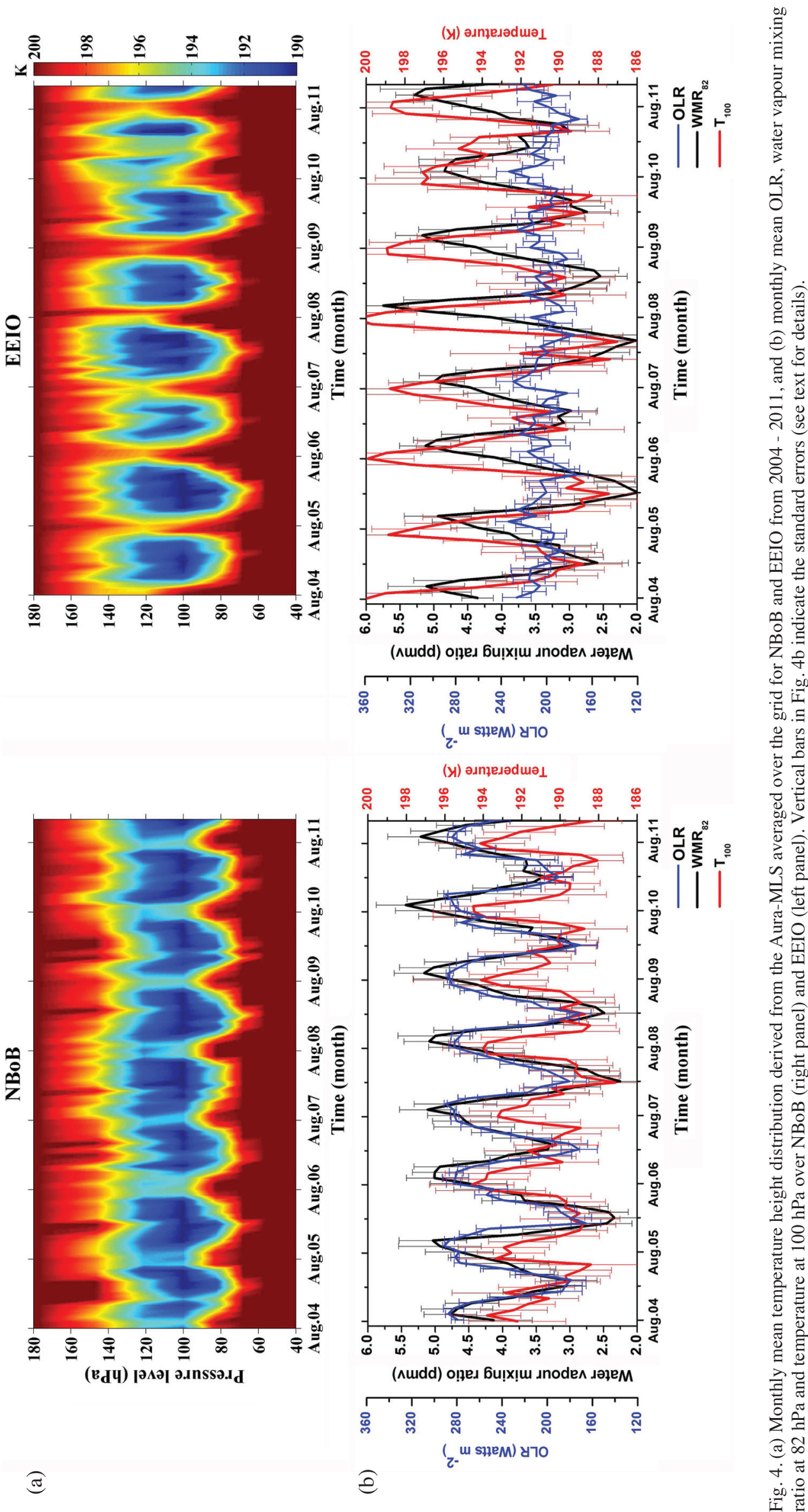

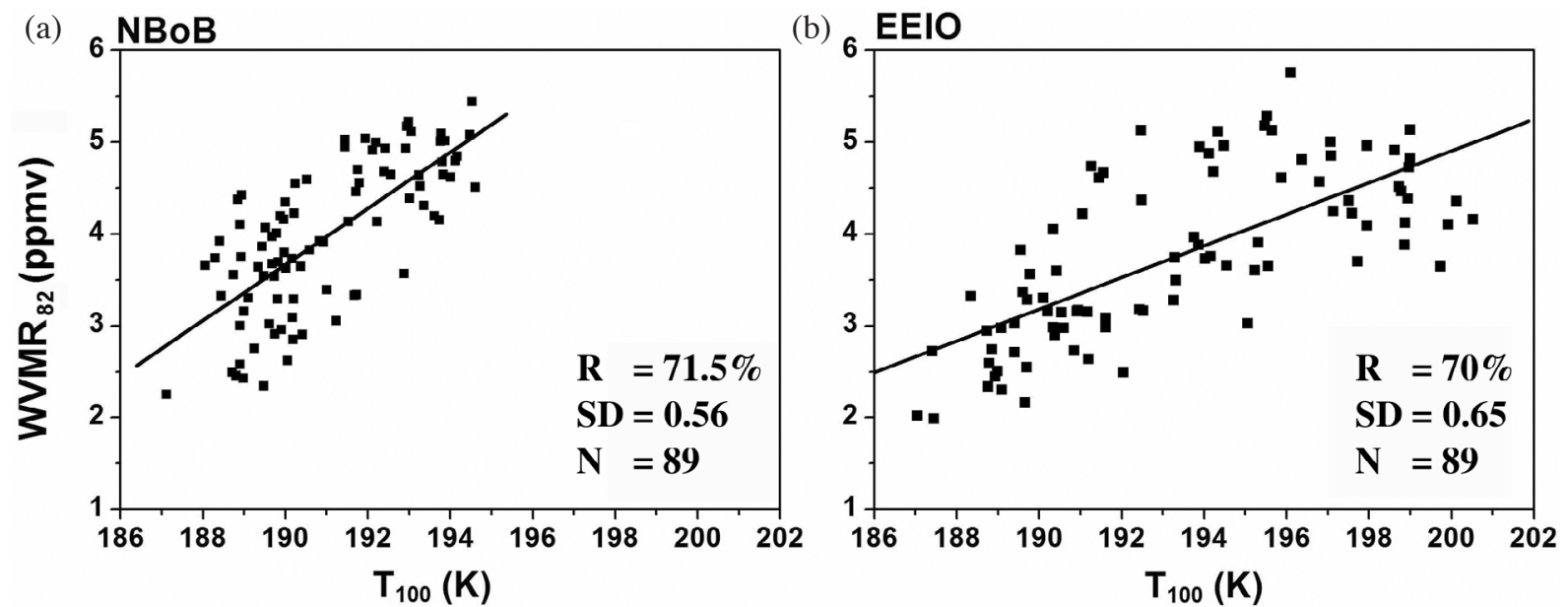

Fig. 5. Scatter plot of water vapor mixing ratio (WVMR) at $82 \mathrm{hPa}$ and temperature at $100 \mathrm{hPa}$ over NBoB (a) and EEIO (b). The letters R, SD and $\mathrm{N}$ indicate the correlation coefficient, standard deviation and number of points, respectively. Data considered for the present analysis from August 2004 to December 2011.

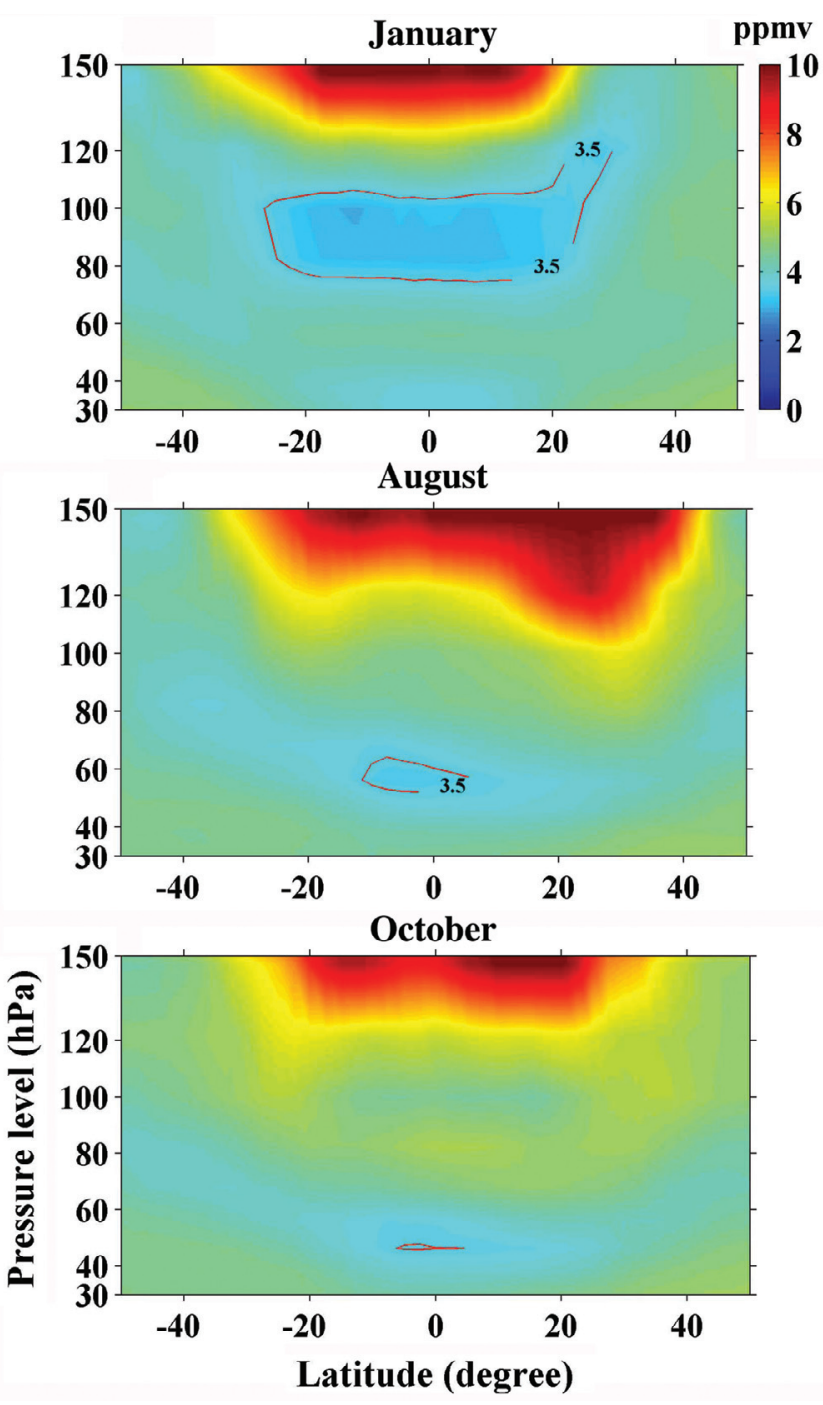

Fig. 6. Water vapor mixing ratio latitude-height distribution for January, August, and October averaged from 2005 - 2011. The closed red contour indicates the water vapour mixing ratio less than 3.5 ppmv. are representative of seasons viz., the Northern hemispheric-winter, monsoon and post-monsoon. The closed red contours in Fig. 6 indicates the water vapor mixing ration $<3.5$ ppmv. Note that during January a band of dry air is observed just above the tropopause, as it gets dehydrated due to the extreme cold tropopause. This dry band shifts upward, centered around $50 \mathrm{hPa}$ during the month of August as it ascends with time due to large-scale vertical motions in the stratosphere. One can also notice the moist air immediately above the tropopause during the month of $\mathrm{Au}-$ gust as the moist air overshoots above the tropopause due to the prevailing warmth in the tropopause. The dry air that entered in the lower stratosphere in the month of January shifts to higher heights during the month of October. Hence the above results indicate that during the month of August, more moist air is pumped into the tropical stratosphere due to the prevailing deep convection with the warmer tropopause temperature, whereas during the other months it gets dehydrated as it encounters the cold tropopause temperature. Thus, the present results suggest that the ASM region takes part in tropical stratosphere hydration. However, the possibility of dehydration in the tropical stratosphere during the ASM in discrete episodes is not ruled out. It is envisaged that this study will have important implications as the water vapor distribution in the UTLS regions influences the balance of planetary radiation and also in the UTLS chemistry.

\section{CONCLUDING REMARKS}

The Aura-MLS water vapor observations were analyzed over two important geographical locations viz. the North Bay of Bengal and East Equatorial Indian Ocean. This study clearly showed that during June - September deep convection prevails over these regions due to the Asian 
Summer monsoon, which pumps the water vapor from the lower troposphere into the tropopause. The overshooting air parcel above $100-82 \mathrm{hPa}$ moves with an ascent rate of $2.8 \times 10^{-4} \mathrm{~m} \mathrm{~s}^{-1}$ and takes around $10-12$ months to reach $30 \mathrm{hPa}$. It is clearly observed that this air parcel retains its identity until it reaches $30 \mathrm{hPa}$. The latitude height section of water vapour also revealed that the moist air is pumped into the stratosphere only during the month of August. The analyses showed that hydration of the stratosphere is due to the warmer tropopause prevailing during the month of $\mathrm{Au}$ gust, which creates a pathway for the entry of more moist air into the stratosphere. The availability of water vapor in the VOT, which is contributed by the Asian Summer monsoon is the critical water vapor contributor. This study therefore provides observational evidence for the role of tropopause temperature and the Asian Summer monsoon in hydrating the tropical stratosphere, rather than dehydrating it as reported earlier. These results will have important implications in understanding the exchange processes between the troposphere and stratosphere.

Acknowledgements The Aura-MLS data were obtained through the NASA. NCEP/NCAR reanalysis data were obtained through (http://www.cdc.noaa.gov), Boulder, Colorado. The authors thank Dr. Rajeev, SPL, for useful discussions during the initial stage of this study. The support and encouragement provided by the Director, SPL are greatly appreciated.

\section{REFERENCES}

Bannister, R. N., A. O'Neill, A. R. Gregory, and K. M. Nissen, 2004: The role of the south-east Asian monsoon and other seasonal features in creating the 'tape-recorder' signal in the unified model. Q.J.R. Meteorol. Soc., 130, 1531-1554, doi: 10.1256/qj.03.106. [Link]

Brewer, A. W., 1949: Evidence for a world circulation provided by the measurements of helium and water vapour distribution in the stratosphere. Q.J.R.Meteorol.Soc., 75, 351-363, doi: 10.1002/qj.49707532603. [Link]

Danielsen, E. F., 1982: A dehydration mechanism for the stratosphere. Geophys. Res. Lett., 9, 605-608, doi: 10. 1029/GL009i006p00605. [Link]

Das, S. S., A. K. Ghosh, K. Satheesan, A. R. Jain, and K. N. Uma, 2010: Characteristics of atmospheric turbulence in terms of background atmospheric parameters inferred using MST radar at Gadanki $\left(13.5^{\circ} \mathrm{N}, 79.2^{\circ} \mathrm{E}\right)$. Radio Sci., 45, RS4008, doi: 10.1029/2009RS004256. [Link]

Froidevaux, L., N. J. Livesey, W. G. Read, Y. B. Jiang, C. Jimenez, M. J. Filipiak, M. J. Schwartz, M. L. Santee, H. C. Pumphrey, J. H. Jiang, D. L. Wu, G. L. Manney, B. J. Drouin, J. W. Waters, E. J. Fetzer, P. F. Bernath, C. D. Boone, K. A. Walker, K. W. Jucks, G. C. Toon, J.
J. Margitan, B. Sen, C. R. Webster, L. E. Christensen, J. W. Elkins, E. Atlas, R. A. Lueb, and R. Hendershot, 2006: Early validation analyses of atmospheric profiles from EOS MLS on the AURA satellite. IEEE Trans. Geosci. Remote Sensing, 44, 1106-1121, doi: 10.1109/ TGRS.2006.864366. [Link]

Fueglistaler, S., M. Bonazzola, P. H. Haynes, and T. Peter, 2005: Stratospheric water vapor predicted from the Lagrangian temperature history of airentering the stratosphere in the tropics. J. Geophys. Res., 110, D08107, doi: 10.1029/2004JD005516. [Link]

Gettelman, A., M. L. Salby, and F. Sassi, 2002: Distribution and influence of convection in the tropical tropopause region. J. Geophys. Res., 107, 4080, doi: 10.1029/2001 JD00 1048. [Link]

Gulstad, L. and I. S. A. Isaksen, 2007: Modeling water vapor in the upper troposphere and lower stratosphere. Terr. Atmos. Ocean. Sci., 18, 415-436, doi: 10.3319/ TAO.2007.18.3.415(EA). [Link]

Highwood, E. J. and B. J. Hoskins, 1998: The tropical tropopause. Q. J. R. Meteorol. Soc., 124, 1579-1604, doi: 10.1256/smsqj.54910. [Link]

Holton, J. R. and A. Gettelman, 2001: Horizontal transport and the dehydration of the stratosphere. Geophys. Res. Lett., 28, 2799-2802, doi: 10.1029/2001GL0131 48. [Link]

Holton, J. R., P. H. Haynes, M. E. McIntyre, A. R. Douglass, R. B. Rood, and L. Pfister, 1995: Stratosphere-troposphere exchange. Rev. Geophys., 33, 403-439, doi: 10. 1029/95RG02097. [Link]

Jain, A. R., S. S. Das, T. K. Mandal, and A. P. Mitra, 2006: Observations of extremely low tropopause temperature over the Indian tropical region during monsoon and postmonsoon months: Possible implications. J. Geophys. Res., 111, D07106, doi: 10.1029/2005JD005850. [Link]

Jain, A. R., V. Panwar, T. K. Mandal, V. R. Rao, A. Goel, R. Gautam, S. S. Das, and S. K. Dhaka, 2010: Mesoscale convection system and occurrence of extreme low tropopause temperatures: observations over Asian summer monsoon region. Ann. Geophys., 28, 927-940, doi: 10.5194/angeo-28-927-2010. [Link]

Kalnay, E., M. Kanamitsu, R. Kistler, W. Collins, D. Deaven, L. Gandin, M. Iredell, S. Saha, G. White, J. Woollen, Y. Zhu, A. Leetmaa, and R. Reynolds, 1996: The NCEP/NCAR 40-year reanalysis project. Bull. Amer. Meteorol. Soc., 77, 437-471, doi: 10.1175/1520-0477 (1996)077<0437:TNYRP>2.0.CO;2. [Link]

Kley, D., E. J. Stone, W. R. Henderson, J. W. Drummond, W. J. Harrop, A. L. Schmeltekopf, T. L. Thompson and R. H. Winkler, 1979: In situ measurements of the mixing ratio of water vapor in the stratosphere. J. Atmos. Sci.,36,2513-2524, doi: 10.1175/1520-0469(1979)036 $<2513$ :SMOTMR>2.0.CO;2. [Link] 
Lambert, A, W. G. Read, N. J. Livesey, M. L. Santee, G. L. Manney, L. Froidevaux, D. L. Wu, M. J. Schwartz, H. C. Pumphrey, C. Jimenez, G. E. Nedoluha, R. E. Cofield, D. T. Cuddy, W. H. Daffer, B. J. Drouin, R. A. Fuller, R. F. Jarnot, B. W. Knosp, H. M. Pickett, V. S. Perun, W. V. Snyder, P. C. Stek, R. P. Thurstans, P. A. Wagner, J. W. Waters, K. W. Jucks, G. C. Toon, R. A. Stachnik, P. F. Bernath, C. D. Boone, K. A. Walker, J. Urban, D. Murtagh, J. W. Elkins, and E. Atlas, 2007: Validation of the Aura Microwave Limb Sounder middle atmosphere water vapor and nitrous oxide measurements. J. Geophys. Res., 112, D24S36, doi: 10.1029/2007JD008724. [Link]

Lelieveld, J., C. Brühl, P. Jöckel, B. Steil, P. J. Crutzen, H. Fischer, M. A. Giorgetta, P. Hoor, M. G. Lawrence, R. Sausen, and H. Tost, 2007: Stratospheric dryness: Model simulations and satellite observations. Atmos. Chem. Phys., 7, 1313-1332, doi: 10.5194/acp-7-13132007. [Link]

Levine, J. G., P. Braesicke, N. R. P. Harris, N. H. Savage, J. A. Pyle, 2007: Pathways and timescales for troposphere-to-stratosphere transport via the tropical tropopause layer and their relevance for very short lived substances. J. Geophys. Res., 112, D04308, doi: 10.1029/ 2005JD006940. [Link]

Livesey, N. J., W. G. Read, L. Froidevaux, A. Lambert, G. L. Manney, H. C. Pumphrey, M. L. Santee, M. J. Schwartz, S. Wang, R. E. Cofeld, D. T. Cuddy, R. A. Fuller, R. F. Jarnot, J. H. Jiang, B. W. Knosp, P. C. Stek, P. A. Wagner, and D. L. Wu, 2011: Earth Observing System (EOS), Aura Microwave Limb Sounder (MLS), version 3.3 level 2 data quality and description document. Jet Propulsion Laboratory, California Institute of Technology, Pasadena, California, USA, available at http://mls.jpl.nasa.gov/data/v3-3 data quality document.pdf.

Mote, P. W., K. H. Rosenlof, M. E. McIntyre, E. S. Carr, J. C. Gille, J. R. Holton, J. S. Kinnersley, H. C. Pumphrey, J. M. Russell III, and J. W. Waters, 1996: An atmospheric tape recorder: The imprint of tropical tropopause temperatures on stratospheric water vapor. $J$. Geophys. Res., 101, 3989-4006, doi: 10.1029/95JD034 22. [Link]

Newell, R. E. and S. Gould-Stewart, 1981: A stratospheric fountain? J. Atmos. Sci., 38, 2789-2796, doi: 10.1175/ 1520-0469(1981)038<2789:ASF>2.0.CO;2. [Link]

Newell, R. E., J. W. Kidson, and D. G. Vincent, 1969: Annual and Biennial modulations in the tropical Hadley cell circulation. Nature, 222, 76-78, doi: 10.1038/222 076a0. [Link]

Park, M., W. J. Randel, A. Gettelman, S. T. Massie, and J. H. Jiang, 2007: Transport above the Asian summer monsoon anticyclone inferred from Aura Microwave Limb Sounder tracers. J. Geophys. Res., 112, D16309, doi: 10.1029/2006JD008294. [Link]

Potter, B. E. and J. R. Holton, 1995: The role of monsoon convection in the dehydration of the lower tropical stratosphere. J. Atmos. Sci., 52, 1034-1050, doi: 10.11 75/1520-0469(1995)052<1034:TROMCI>2.0.CO;2. [Link]

Randel, W. J., F. Wu, and D. J. Gaffen, 2000: Interannual variability of the tropical tropopause derived from radiosonde data and NCEP reanalyses. J. Geophys. Res., 105, 15509-15523, doi: 10.1029/2000JD900155. [Link]

Randel, W. J., F. Wu, A. Gettelman, J. M. Russell III, J. M. Zawodny, and S. J. Oltmans, 2001: Seasonal variation of water vapor in the lower stratosphere observed in Halogen Occultation Experiment data. J. Geophys. Res., 106, 14313-14325, doi: 10.1029/2001JD900048. [Link]

Randel, W. J., E. Moyer, M. Park, E. Jensen, P. Bernath, K. Walker, and C. Boone, 2012: Global variations of HDO and $\mathrm{HDO} / \mathrm{H}_{2} \mathrm{O}$ ratios in the upper troposphere and lower stratosphere derived from ACE-FTS satellite measurements. J. Geophys. Res., 117, D06303, doi: 10.10 29/2011JD016632. [Link]

Rao, T. N., K. N. Uma, D. N. Rao, and S. Fukao, 2008: Understanding the transportation process of tropospheric air entering the stratosphere from direct vertical air motion measurements over Gadanki and Kototabang. Geophys. Res. Lett., 35, L15805, doi: 10.1029/2008GL 034220. [Link]

Read, W. G., A. Lambert, J. Bacmeister, R. E. Cofield, L. E. Christensen, D. T. Cuddy, W. H. Daffer, B. J. Drouin, E. Fetzer, L. Froidevaux, R. Fuller, R. Herman, R. F. Jarnot, J. H. Jiang, Y. B. Jiang, K. Kelly, B. W. Knosp, L. J. Kovalenko, N. J. Livesey, H.-C. Liu, G. L. Manney, H. M. Pickett, H. C. Pumphrey, K. H. Rosenlof, X. Sabounchi, M. L. Santee, M. J. Schwartz, W. V. Snyder, P. C. Stek, H. Su, L. L. Takacs, R. P. Thurstans, H. Vömel, P. A. Wagner, J. W. Waters, C. R. Webster, E. M. Weinstock, and D. L. Wu, 2007: Aura Microwave Limb Sounder upper tropospheric and lower stratospheric $\mathrm{H}_{2} \mathrm{O}$ and relative humidity with respect to ice validation. J. Geophys. Res., 112, D24, doi: 10.1029/2007JD008752. [Link]

Schoeberl, M. R., A. E. Dessler, and T. Wang, 2012: Simulation of stratospheric water vapor and trends using three reanalyses. Atmos. Chem. Phys., 12, 6475-6487, doi: 10.5194/acp-12-6475-2012. [Link]

Selkirk, H. B., 1993: The tropopause cold trap in the Australian monsoon during STEP/AMEX 1987. J. Geophys. Res., 98, 8591-8610, doi: 10.1029/92JD02932. [Link]

Sherwood, S. C. and A. E. Dessler, 2000: On the control of stratospheric humidity. Geophys. Res. Lett., 27, $2513-$ 2516, doi: 10.1029/2000GL011438. [Link] 
Sherwood, S. C. and A. E. Dessler, 2001: A model for transport across the tropical tropopause. J. Atmos. Sci., 58, 765-779, doi: 10.1175/1520-0469(2001)058<0765:A MFTAT>2.0.CO;2. [Link $]$

Smith, C. A., R. Toumi, and J. D. Haigh, 2000: Seasonal trends in stratospheric water vapour. Geophys. Res. Lett., 27, 1687-1690, doi: 10.1029/1999GL011160. [Link]

Wang, P. K., M. Setvák, W. Lyons, W. Schmid, and H. M. Lin. 2009: Further evidences of deep convective vertical transport of water vapor through the tropopause. Atmos. Res., 94, 400-408, doi: 10.1016/j.atmosres.2009. 06.018. [Link]

Wang, P. K., S. H. Su, Z. Charvát, J. Št'ástka, and H. M. Lin, 2011: Cross tropopause transport of water by mid-latitude deep convective storms: A review. Terr. Atmos. Ocean. Sci., 22, 447-462, doi: 10.3319/TAO.2011.06. 13.01(A). [Link]

Waters, J. W., L. Froidevaux, R. S. Harwood, R. F. Jarnot, H. M. Pickett, W. G. Read, P. H. Siegel, R. E. Cofield,
M. J. Filipiak, D. A. Flower, J. R. Holden, G. K. Lau, N. J. Livesey, G. L. Manney, H. C. Pumphrey, M. L. Santee, D. L. Wu, D. T. Cuddy, R. R. Lay, M. S. Loo, V.S.Perun, M. J. Schwartz, P. C. Stek, R. P. Thurstans, M. A. Boyles, K. M. Chandra, M. C. Chavez, G. S. Chen, B. V. Chudasama, R. Dodge, R. A. Fuller, M. A. Girard, J. H. Jiang, Y. Jiang, B. W. Knosp, R. C. LaBelle, J. C. Lam, K. A. Lee, D. Miller, J. E. Oswald, N. C. Patel, D. M. Pukala, O. Quintero, D. M. Scaff, W. Van Snyder, M. C. Tope, P. A. Wagner, and M. J. Walch., 2006: The Earth Observing System Microwave Limb Sounder (EOS MLS) on the Aura satellite. IEEE Trans. Geosci. Remote Sensing, 44, 1075-1092, doi: 10.1109/TGRS.2006.873771. [Link]

Wright, J.S., R. Fu, S. Fueglistaler, Y. S. Liu, and Y. Zhang, 2011: The influence of summertime convection over southeast Asia on water vapor in the tropical stratosphere. J. Geophys. Res., 116, D12302, doi: 10.1029/ 2010JD015416. [Link] 